\title{
ANALISIS MANAJEMEN SDM DALAM MENGEMBANGKAN STRATEGI PEMBELAJARAN DI ERA NEW NORMAL
}

\section{Syamsul Bahri, Novira Arafah, ${ }^{2}$}

Pascasarjana Institut Pesantren KH. Abdul Chalim, ${ }^{1,2}$

Email: syamsulbahriabdullah7@gmail.com, novira.arafah2121@gmail.com

\begin{tabular}{l}
\hline \\
\hline Keywords: \\
Human \\
Resource \\
Management; \\
Learning \\
Strategies; \\
New Normal \\
Era \\
\hline
\end{tabular}

Kata kunci:

Manajemen

Sumber Daya

Manusia;

Strategi

Pembelajaran;

New Normal

\begin{abstract}
This literature study was conducted to find out: Analysis of Human Resource Management in Improving Strategies Learrning in the New Normal Era. In this research, the method used qualitative with a library research. The results of the study indicate are: Human Resource management in improving strategies learrning in the new normal era is effort, mature readiness, provisioning both in terms of IT skills and virtual learning progress. The most appropriate learning strategy in the new normal era is to follow the rules of the Ministry of Education and Culture with virtual learning through agreed platforms. For this reason, the 2 main elements of teaching and learning activities take place, these students and teachers must be equipped, qualified and know the direction of learning that will be filtered in order to minimize misunderstanding between teacher and students. While students at home, study is assisted and supervised by their parents to avoid deception, laziness and cheating during the exam. So that ethics, values / norms remain upheld in the world of academia.
\end{abstract}

\section{Abstrak}

Studi pustaka ini dilakukan untuk mengetahui: Analisis Manajemen Sdm Dalam Meningkatkan Strategi Pembelajaran Di Era New Normal. Dalam penelitian ini, metode yang digunakan ialah kualitatif dengan pendekatan studi kepustakaan (library research). Hasil dari penelitian menunjukkan bahwa: Manajemen SDM dalam meningkatkan strategi pembelajaran di era new normal adalah dengan upaya, kesiapan matang, pembekalan baik dari segi kecakapan TI dan keterbiasaan berlangsungnya virtual learnig. Strategi pembelajaran yang paling tepat dalam era new normal ini ialah mengikuti aturan Kemendikbud dengan pembelajaran virtual melalui platform-platform yang telah disepakati. Untuk itu 2 elemen pokok berlangsung kegiatan belajar-mengajar, siswa dan guru ini harus dibekali, mumpuni dan tau arah belajar yang akan filterisasi agar meminimalisir kesalahanpahaman antara guru dan siswa. Sementara siswa, di rumah, belajar dibantu dan diawasi oleh orangtuanya agar 
tidak terjadi tipu daya, kemalasan dan kecurangan saat

pelaksanaan ujian. Sehingga etika, nilai/norma tetap

dijunjung tinggi dalam dunia akademisi.

\section{PENDAHULUAN}

Secara sadar, kita mengetahui bahwasannya maanajemen sumber daya manusia merupakan bagian inti/pokok dalam suatu asosiasi ataupun naungan lembaga pendidikan. Tak luput dalam ini, bagaimana sumber daya manusia itu sendiri mendedikasikan diri untuk menyambut masa beralihnya normal (seperti sedia kala) menjadi pandemi (sebab telah menimpa puluhan Negara di dunia) menjadi new normal (normal dengan kebiasaan baru). Mengapa dipilih era new normal bukan normal semula? Sebab dalam masa ini kita telah dituntut untuk siap, setelah beberapa bulan menahan diri layaknya proses berpuasa dari yang namanya keluar rumah unutk hal yang tidak dibutuhkan. Bahkan sebagian orang diharuskan untun berdiam diri hingga waktu yang belum ditentukan sebagai bentuk ikhtiar atas pandemi yang memungkinkan menimpa yang tak pilah-pilih/kenal siapapun. Hampir lebih dari 3 bulan baik instatnsi pemerintahan, pendidikan dan elemen yang kira-kira membutuhaan terlalu banyak kontak fisik harus dihentikan sementara waktu guna mengikuti aturan jaga jarak (phsycal distancing) untuk mencegah virus yang cepat berkembang ini menyebar. Menyangkut dunia pendidikan, dimana anak-anak libur lebih lama dari biasanya, bahkan berdasarkan kacamata yang dilihat sekarang, kebosanan dan kejenuhan mulai menghias diri seperti dalih yang merindukan, guru, teman sebayanya, pelajaran disekolah dan aktivitas yang biasanya ia jalani. Memang, lembaga pendidikan juga mengikuti alur yang cepat tanggap sehingga tetap mengadakan pembelajaran yang difungsikan dengan daring method.

Strategi pembelajaran mengacu era new normal dipandu dengan mengikuti protokol kesehatan dan memicu guru sebagai bagian dari SDM terpenting dalam kegiatan belajar-mengajar untuk mempunyai jurus jitu mengelola belajar tanpa tatap muka disertai tidak menghilangkan learning essention itu sendiri. Seperti yang beredar di media social saat ini, guru kerap kali memberikan contoh lalu membagian link dan meminta siswa mengikutinya dirumah merupakan cara efisien yang ditempuh untuk belajar di tengah pandemi dengan new normal era. 
Tetapi ketidakefektifan baik dari SDM dalam hal ini pendidik, murid maupun orang tua menemukan berbagai kendala dengan metode virtual yang diterapkan pada perabadan baru kehidupan manusia ini. Olehnya, SDM haruslah terbiasa dengan dayanya untuk meningkatkan dengan berinovasi dengan strategistrategi baru guna kelancaran KBM dengan era yang saat ini tengah dijalani. Para ahli juga telah jauh-jauh hari meneliti sehingga penemuannya sebagaimana berikut yang dikemukakan oleh Ni'mah bahwa: ada juga kendala dari E- learning ini, yaitu: 1) Listrik bisa padam ketika sedang menakses program pembelajaran 2) Jaringan internet yang buruk 3) Komitmen dari orangtua yang tidak menentu 4) Mahasiswa/siswa yang sulit belajar dengan cara ini 5) Kesalahpahaman antara dosen/guru dan maha/siswa 6) Ketidaktahuan IPTEK.1

\section{METODE PENELITIAN}

Studi yang dilakukan ini merupakan sebuah studi literatur (literature review) yaitu sebuah pencarian dan merangkum beberapa literatur empiris yang sesuai dan relevan dengan tema. Literatur yang digunakan berupa buku, artikel ilmiah yang berasal dari jurnal internasional maupun nasional. Literatur yang digunakan adalah literatur relevan dengan studi ini dan telah dicetak maupun dipublikasikan. Penggunaan kriteria inklusi dan eksklusi terhadap seluruh literatur merupakan metode penyeleksiannya.

\section{HASIL PENELITIAN DAN PEMBAHASAN}

\section{Manajemen Sumber Daya Manusia}

Manajemen sumber daya manusia bukanlah suatu tujuan dan akhir suatu proses, melainkan suatu perangkat atau alat untuk membantu tercapainya suatu tujuan secara keseluruhan. Untuk itu, satu bagian/unit manajemen sumber saya manusia di suatu lembaga diadakan untuk melayani bagian-bagian lain lembaga maupun organisasi. Manajemen Sumber Daya Manusia diartikan oleh Mangkunegara sebagai suatu pengolahan dan pendayagunaan sumber daya yang ada pada individu. Dalam arti lain merupakan suatu perencanaan, pengorganisasian, pelaksanaan pengawasan terhadap pengadaan, pengembangan, pemberian balas jasa, pengintegrasian, pemeliharaan dan pemisahaan tenaga kerja dalam rangka mencapai tujuan suatu lembaga.

\footnotetext{
${ }^{1}$ Ridho Rizqulloh, "E-Learning dan Pembelajaran Jarak Jauh (PJJ) Saat Masa Pandemi Covid-19," April 2020, 6, https://www.researchgate.net/publication/340920188\%0AARTIKEL.
} 
Tafkir: Interdisciplinary Journal of Islamic Education

Vol.1, No.1, June 2020, , DOI:

Hal: 20-40, E-ISSN-

Manajemen sumber daya manusia di setiap lembaga/organisasi haruslah sesuai dengan tujuan organisasi dengan tidak berlebihan ataupun tidak terlalu kurang. Sebab, adanya suatu kelebihan atau kekurangan penerapan sasaran di masing-masing unit lembaga menunjukkan adanya wasted atau pemborosan penggunaan sumber daya manusia. Maka dari itu setiap unit lembaga yang mengelola atau menggunakan sumber daya manusia harus mampu menjaga keseimbangan yang tepat antara kualitas dan kuantitas sumber dayanya masingmasing. Agar selaras dengan tujuan yang telah ditetapkan. ${ }^{2}$

Dengan kata lain, yang perlu dan utama di manajemen dalam hal ini ialah 3 komponen SDM, yaitu guru sebagai tenaga pendidik, murid selaku peserta didik dan orang utama sebagai pemangku kepentingan pendidikan. Serta keterkaitan untuk berpartisipasi antara masyarakat dan orang tua merupakan hal utama yang tak kalah pentingnya.

Menjalin kerjasama antara sekolah dengan masyarakat merupakan bentuk kegiatan yang dilakukan baik secara langsung maupun tidak. Misalnya bantuan dan dukungan dari pihak yang ada di lingkungan sekitar pendidikan. Walaupun, seluruh lapisan masyarakat belum sepenuhnya nyata dalam bersumbangsih, tetapi lembaga pendidikan harus terus ontimis dan gencar untuk melakukan sosialisasi dan aktivitas yang saling berkaitan untuk keoptimalan tujuan yang dicapai (Setiana, 2018). Sebagai bagian komponen mikro penentu dominan mutu pendidikan, guru haruslah bermutu dan berkinerja baik dalam globalisasi dengan barusaha menguasai berbagai teknologi informasi dan komunikasi. Sebab, kemajuan aspek informasi dan komunikasi mengalami perubahan yang dahsyat dalam era globalisasi. Dalam sistem pendidikan nasional guru memiliki peranan strategis pada proses pembelajaran secara khusus dan proses pendidikan secara keseluruhan. ${ }^{3}$

Khususnya di tengah pandemik dan masa transisi new normal era saat ini. Penting sekali bagi 2 elemen pokok di atas saling sharing dan caring untuk dapat mengimbangi kondisi psikis anak yang tertekan dengan keterbatasan aktivitas yang memungkinkan berdampak stessor. Jadi, hal ini dapat dicegak melalui menimilisir

\footnotetext{
${ }^{2}$ Aprilianto, Manajemen SDM, (Yogyakarta: Bening Pustaka. 2019), 10.

${ }^{3}$ Kartiko, Manajemen Mutu Pendidikan, (Yogyakarta: Bening Pustaka, 2019),
} 
kesenjangan dengan rutinitas yang tetap berjalan dengan pengawasan ekstra dari era normal sebelumnya.

\section{Cara-cara Penanganan Perubahan}

Pergeseran paradigma dalam mengelola organisasi di era unpredictable serta kompleks membuat organisasi untuk perlu melakukan penyesuaian melalui sebuah proses perubahan. Perubahan organisasi adalah usaha untuk mempertahankan kelangsungan hidup agar tetap survive menghadapi permasalahan yang tidak pasti seperti Covid-19. Organisasi-organisasi yang cepat beradaptasi dengan perubahan lingkungan adalah organisasi yang survive. ${ }^{4}$

Ada 2 pendekatan utama penanganan perubahan organisasi yang dapat digunakan para manajer, seperti ditunjukkan di bawah ini:

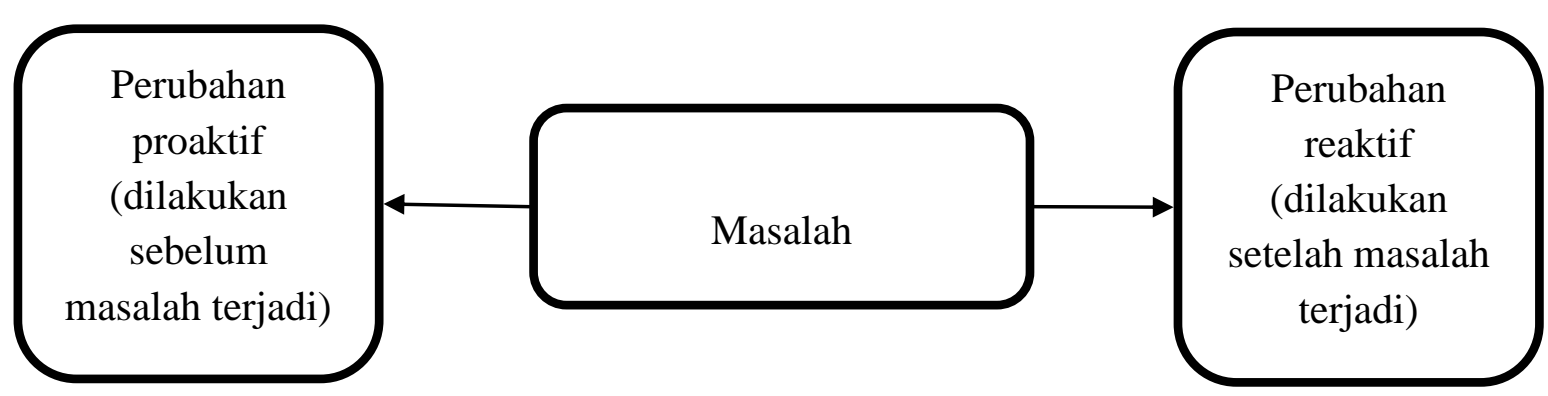

Pertama, adalah proses perubahan reaktif, dimana pemimpin beraksi atas tanda-tanda bahwa perubahan dibutuhkan, pelaksanaan modifikasi sedikit demi sedikit untuk menangani masalah-masalah tertentu yang timbul. Kedua, pemimpin mengembangkan suatu program perubahan yang direncanakan (planned change), yang sering disebut sebagai proses proaktif, melalui pelaksanan berbagai investasi waktu dan sumber daya lainnya yang berarti untuk mengubah cara-cara operasi lembaga/organisasi. Pendekatan pertama, lebih sederhana dan lebih murah dibanding pendekatan kedua. Diperlukan pemimpin dalam pemecahan masalah sederhana (kecil) dan penyesuaian hari ke hari yang integral dengan jabatannya.

Pendekatan kedua, program poerubahan yang ditrencanakan menyangkut kegiatan-kegiatan yang disengaja untuk mengubah status quo. Thimas dan Bennis mendefinisikan perubahan yang direncanakan sebagai perancangan dan implementasi inovasi struktural, kebijaksanaan atau tujuan baru, atau suatu

\footnotetext{
${ }^{4}$ Hardi Warsono Taufik, "Birokrasi Baru Untuk New Normal: Tinjauan Model Perubahan Birokrasi Dalam Pelayanan Publik di Era Covid-19, ” Dialogue: Jurnal Ilmu Administrasi Publik, Vol. 2 No. 1, Juni 2020, 16, https://www.researchgate.net/publication/340920188\%0AARTIKEL.
} 
Tafkir: Interdisciplinary Journal of Islamic Education

Vol.1, No.1, June 2020, , DOI:

Hal: 20-40, E-ISSN-

perubahan dalam filsafat, iklim dan pengoperasian secara sengaja. Pendekatan ini tepat apabila keseluruhan lembaga/organisasi harus menyiapkan diri untuk atau menyesuaikan dengan perubahan. 5

Hal ini dapat di lihat dari merebaknya pandemi yang terjadi dia dunia khususnya di Negara kita tercinta, Indonesia dengan khas lagu kebangsaannya Indonesia Raya. Relevansinya, kita memang benar-benar perlu mengadakan reaksi sesuai dengan pendekatan kedua dari pendapat ahli di atas. Sebab, pandemi ini tidak bias ditebak kapan berakhir secara tuntasnya. Wallahu'alam. Tugas kita sebagai akademisi ialah selalu melakukan ikhtiar dengan mempercayakan pada para ahli yaitu medis dan Dinas Pendidikan yang telah bersusah payah merancang atau merenovasi pembaruan pendidikan yang disesuaikan dengan era new normal yang sedang berangsur diterapkan di persebaran 34 provinsi Indonesia.

Salah satu upayanya ialah dengan active mengikuti Webinar di masa pandemi. Dari sini kita bisa sharing secara langsung dengan perancang, penggagas dan pembuat kebijakan di Indonesia walau dengan limited time yang ditentukan. Selaras dengan ungkapan Kemendikbud, Romi menuturkan dari akhir kesimpulan webinar yang diadakan pada Senin/07/07/2020 bahwa kita perlu saling mengisi, mengajari, sharing pengalaman dan kolaborasi. Serupa Miss Riska selaku pengelola lembaga pendidikan KAIZEN pada kesempatan ini pun mengemukakan pentingnya kolaborasi antara lingkungan sekolah dan lingkungan sekitar di tengah pandemi ini.

\section{Pengembangan Kemampuan SDM}

1. Pelayanan yang baik hanya akan dapat terwujud apabila manajemen SDM dilakukan dengan mengedepankan kepentingan pengguna jasa pendidikan ${ }^{6}$.

2. Komunikasi. Purwanto dalam bukunya mengemukakan komunikasi sebagai perantara dari penyampaian ideologi seseorang kepada orang lain pastinya memiliki kendala dan hambatan yang dapat memicu kesalahpahaman. Faktorfaktor penghambat komunikasi terdapat dalam beberapa hal antara lain "masalah dalam pengembangan pesan, masalah dalam penyampaian pesan,

\footnotetext{
${ }^{5}$ Handoko, T. H, Manajemen, (Yogyakarta: BPFF, 1991), 22-23.

${ }^{6}$ Winarsih, R. d, Manajemen Pelayanan: Pengembangan Model Konseptual, Penerapan Citizen's Charter dan Standar Pelayanan Minimal, (Yogyakarta: Pustaka Pelajar, 2016),
} 
masalah dalam penerimaan pesan dan masalah dalam penafsiran pesan"7. Sebagaimana Rizal pun mengungkapkan, komunikasi antara pendidik dan peserta didik berlangsung dua arah yang dijembatani oleh penggunaan media, seperti komputer, televisi, radio, telepon, internet, video, dan sebagainya ${ }^{8}$.

3. Jejaring global, tahapan ini dimulai dari pertengahan tahun 1990-an. Disebut dengan jejaring global karena perusahaan-perusahaan sudah dihubungkan dengan jaringan system teknologi informasi secara global dengan teknologi telekomunikasi melalui internet, yang juga popular dengan sistem teknologi informasi. Dengan hal lain dilakukan penekanan terhadap aplikasi informasi ${ }^{9}$.

4. Siklus PDCA (Plan, Do, Check dan Act) dan SDCA (Standardize, Do, Check, dan Act)

Pakar ahli Edward Deming sebagai pengagas siklus ini, merupakan siklus untuk melakukan perbaikan proses continue dan pengendalian yang meliputi langkah berikut:

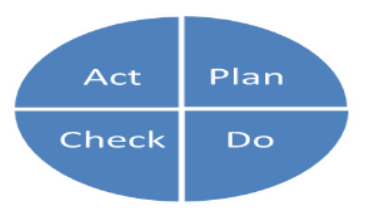

\section{Langkah-langkah}

Plan

Do
Check

Act
1. Identifikasi masalah utama

2. Meneliti penyebab utama

3. Menentukan penyebab yang berpengaruh.

4. Rencana perbaikan, menetapkan sasaran

5. Tanggung jawab dan pelaksanaan rencana

6. Evaluasi dan validasi pelaksanaan

7. Kaji semua feedback, lakukan perbaikan

8. Memperbaiki standar

\footnotetext{
${ }^{7}$ Basthoumi Muslih, “Urgensi Komunikasi Dalam Menumbuhkan Motivasi di Era, ” Jurnal Penelitian Manajemen Terapan (PENATARAN), Vol 5 No. 1, 2020, 60, http://journal.stieken.ac.id/index.php/penataran/article/view/463.

8 Iqbal Faza Ahmad, "Alternative Assessment in Distance Learning in Emergencies Spread of Coronavirus Disease (Covid-19) in Indonesia,” Jurnal Pedagogik, Vol. 07 No. 01, 2020, 200, https://ejournal.unuja.ac.id/index.php/pedagogik\%0AALTERNATIVE.

${ }^{9}$ Jogiyanto H.M, Sistem Informasi Manajemen, (Tangerang Selatan: Universitas Terbuka.2018), 211.
} 
Tafkir: Interdisciplinary Journal of Islamic Education

Vol.1, No.1, June 2020, , DOI:

Hal: 20-40, E-ISSN-

Mula-mula perbaikan, setiap proses baru biasanya belum stabil. Sebelum melakukan perbaikan untuk siklus berikutnya, proses baru distabilkan melalui SDCA yang sifatnya sebagai pemeliharaan. Berikut gambar pemeliharaan SDCA:

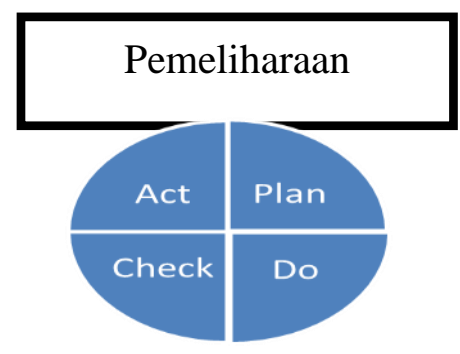

Gambar 1. (Pemeliharaan SDCA)

Ketika ketidakwajaran timbul dalam suatu proses baru, beberapa pertanyaan harus diajukan sebagai bahan koreksi, yaitu apakah hal tersebut terjadi karena tidak memiliki standar atau standar tidak dipatuhi, bisa jadi kurang rinci atau tidak rinci. Setelah standar disempurnakan dan dipatuhi serta membawa kestabilan proses diperkenankan beralih ke siklus PDCA selanjutnya. Hal ini menandakan diklus SDCA menerapkan standarisasi guna mencapai kestabilan proses yang berfungsi pemeliharaan, sementara siklus PDCA menerapkan fungsi perbaikan dan pengendalian ${ }^{10}$.

Masa transisi ini benar-benar harus dipersiapkan, mulai dari pelayanan, komunikasi, jejaring gliobal dan siklus yang ditawarkan oleh Edward Deming di atas. Pelayanan yang ditinjau dari peradaban baru dimana virtual meeting adalah sarana yang telah ditempuh oleh satuan pendidikan kita saat ini dengan berbagai fitures aplikasi yang disediakan, yang paling dominan seperti: zoom, gooegle-meet, live in youtube, ruang guru, ruang belajar serta berbagai macam diskusi online lainnya yang telah digelar di dunia maya. Semua itu juga memiliki dampak dan kendala sebagaimana yang kita ketahui tidak semua anak didik/masyarakat Indonesia menggenggam gadget, akses signal yang kurang memadai untuk daerah pedalaman, kuota internet yang besar pemakaiannya di tengah minimnya penghasilan, serta seorang guru yang harus rela mendatangi siswanya ke rumah demi tetap mendapatkan pendidikan yang

${ }^{10}$ M. Nur. Nasution, Manajemen Mutu Terpadu, (Bogor: Ghalia Indonesia, 2015), 93. 
layak. Apresiasi sekaligus miris, sebab usaha yang sebegitu ekstra dan semboyan guru tanpa tanda jasa yang melekat padanya belum mencapai taraf maksimal dalam pelaksanaan di lapangan.

\section{Menuju New Normal Transition}

Dalam realitas baru, yang belum pernah terjadi sebelumnya, pasca Covid 19 ini, dunia digemparkan dengan istilah new normal, yang membuat restrukturisasi (penataan kembali) kehidupan masyarakat, dan dalam waktu dekat, akan ada perdebatan dan diskusi tentang new normal11. Istilah "new normal" yang berarti normalitas atau kenormalan baru, sudah lama ada dan tidak asing. Langkah pemerintah menerapkan new normal sudah sangat tepat ${ }^{12}$. Adapun bagi civitas madrasah dan sekolah penting sekali meperhatikan langkah langkah tersebut menuju keberhasilan pelaksanaan new normal dengan tentunya memperhatikan prosedur ${ }^{13}$.

Beragam istilah dalam memahami term tersebut, seperti tatanan kehidupan baru (kata bapak Joko Widodo), adaptasi kebiasaan baru (kata bapak Ridwan Kamil), transisi menyambut kenormalan baru (kata bapak Anies Baswedan dan bapak Bima Arya), dan penyesuaian pola hidup (kata wiku Asisasmita selaku ketua tim pakar gugus tugas percepatan covid-1914. Adapun kementrian pendidikan dan kebudayaan (kemendikbud) dalam akun resmi instagramnya menjelaskan bahwa kata new normal memiliki padanan kata dalam Bahasa Indonesia yaitu kenormalan baru yang merupakan keadaan normal yang baru yang belum pernah ada sebelumnya15. Menurut juru bicara pemerintah dalam percepatan penanganan COVID 19, new normal dimaknai sebagai gerakan hidup baru, kehidupan yang produktif dan aman dari wabah

\footnotetext{
${ }^{11}$ Kevin Sneader and Shubham Singhal, "Beyond Coronavirus: The Path to the next Normal," McKinsey \& Company, March 2020, 2.

${ }^{12}$ Wahyudin Darmalaksana, "New Normal Perspektif Sunnah Nabi SAW”, Fakultas Ushuluddin UIN Sunan Gunung Djati Bandung, 2020, 1, http://digilib.uinsgd.ac.id/id/eprint/31093.

${ }^{13}$ Wakhudin Dkk, Covid-19 dalam Ragam Tinjauan. Didik Haryadi Santoso dan Awan Santosa (editor), D.I. Yogyakarta: MBridge Press, 2020), 69. Diakses dari https://scholar.google.co.id/scholar?hl=id\&as_sdt=0\%2C5\&q=Covid19+dalam+Ragam+Tinjauan.\&btnG=, tanggal 8 Juli 2020.

${ }^{14}$ Kurniadi, Menyiapkan Pendidikan Menuju Normal Baru, http://www.untan.ac.id/menyiapkan-pendidikan-menuju-normal-baru/. Diakses Juli 072020.

${ }^{15}$ Albertus Adit, Padanan Kata New Normal dari Badan Bahasa Kemendikbud, https://edukasi.kompas.com/read/2020/05/26/152138171/ini-padanan-kata-new-normal-dari-badanbahasa-kemendikbud. Diakses 7 Juli 2020.
} 
Tafkir: Interdisciplinary Journal of Islamic Education

Vol.1, No.1, June 2020, , DOI:

Hal: 20-40, E-ISSN-

virus corona. Achmad Yurianto mengatakan bahwa kita tidak mungkin kembali pada situasi sebagaimana sebelumnya (normal lama), oleh karena itu kita harus berubah"16.

Substansi dari new normal tidak boleh dianggap sebatas pelonggaran PSBB dan transportasi publik. Meskipun banyak yang terkejut, akhirnya dipahami sebagai sesuatu yang normal dan harus berjalan. Menurut Ridwan Sanjaya mengutip pendapat Paul Glover dalam philadelphia city paper 2009 bahwa dalam menjelaskan kondisi yang semula dinilai tidak umum menjadi sesuatu yang kemudian dianggap biasa, wajar, dan akhirnya diterima secara luas, new normal yang diterima oleh masyarakat tersebut menjadi hal yang kemudian dipahami sebagai kondisi yang wajar. Berbagai perubahan yang terus terjadi ini menciptakan kondisi yang disebut sebagai "the new normal". New normal ditanggapi beragam oleh masyarakat. Hal demikian adalah wajar, selama diniatkan untuk kehidupan yang lebih baik dan dilakukan berdasarkan kajian riset yang valid ${ }^{17}$.

WHO telah menetapkan beberapa barometer sebelum pemerintah menerapkan normal baru, antara lain: memastikan penularan terkendali, sistem kesehatan dalam keadaan baik, jaminan langkah pencegahan di lingkungan kerja, mencegah kasus impor covid, dan memastikan kesadaran dan partisipasi masyarakat ${ }^{18}$. Sejalan dengan itu, pemerintah menentukan tiga standar pengurangan PSBB, yaitu dengan melihat penularan berdasarkan reproduction rate (R0), tingkat kapasitas sistem kesehatan dalam merespon pelayanan Covid19 dan tingkat tes Covid-19 secara massal yang dilakukan ${ }^{19}$.

Melihat dan mencermati standar dan baromater di atas, pakar epidemiologi Universitas Indonesia Pandu Riono, dikutip dari You Tube Kompas TV, Sabtu, 30 Mei 2020 menilai gerakan hidup baru (new normal) belum dapat terlaksana secara menyeluruh, jika parameter kesehatan belum

\footnotetext{
${ }^{16}$ Nefan Kristiono, Pengertian New Normal Versi Achmad Yurianto, https://www.minews.id/news/ini-pengertian-new-normal-versi-achmad-yurianto-2. Diakses 7 Juli 2020.

${ }^{17}$ Ridwan Sanjaya, New Normal dalam Pendidikan Tinggi, http://www.suaramerdeka.com/smcetak/detail/124756. Diakses 7 Juli 072020.

${ }^{18}$ Redaksi WE Online, Syarat Penerapan The New Normal dari WHO Apa saja, https://www.wartaekonomi.co.id/read286402/6-syarat-penerapan-the-new-normal-dari-who-apa-saja. Diakses 07 Juli 72020.

19 Abdul Basith Bardan, Pemerintah Siapkan Tiga Syarat Penyesuaian PSBB, https://nasional.kontan.co.id/news/pemerintah-siapkan-tiga-syarat-penyesuaian-psbb. Diakses 7 Juli 2020.
} 
terpenuhi, disebabkan ketelitian atau keautentikan data covid 19 sehingga sulit menghitung angka reproduction rate $(\mathrm{RO})^{20}$. Menurut Jusuf Kalla, dikutip dari Akurat. Com, Sabtu, 30 Mei 2020, memprediksikan new normal akan berlangsung minimal 3 (tiga) tahun, jika sudah ditemukan vaksin covid 19 pada Februari 2021 dan selanjutnya ialah produksi vaksin secara massal pada Agustus dan September 202121. Banyak negara yang memutuskan kembali pada gerakan hidup baru (new normal) seperti Tiongkok (China dan Korea Selatan namun tetap mengikuti protokol kesehatan. Tetapi akhirnya negara tersebut kembali berlakukan pembatasan sosial.

Fenomena di atas, sepaham dengan maklumat yang sering disampaikan oleh epidemiolog Universitas Indonesia Pandu Riono, dikutip dari Kompas, 29 Mei 2020: "Jika tetap memaksakan diterapkannya fase normal baru, sementara persyaratan dan kriteria yang telah ditentukan belum terpenuhi, maka bersiapsiaplah menanggung peningkatan kasus" 22.

Penulis berpandangan bahwa sebelum menetapkan kembali pada gerakan hidup baru (new normal), sebaiknya didahului tahap transisi, yaitu suatu tahap yang sangat menentukan berhasil tidaknya tahap new normal nantinya.

Ada dua tahap perubahan yang bisa di terapkan yaitu tahap pertama: tahap pemutusan, kemudian tahap kedua, tahap transisi, yakni suatu prosedur dimana keluar dari kebiasaan lama dan masuk ke kebiasaan baru atau dimulai dengan suatu pemutusan dan diakhiri dengan suatu permulaan ${ }^{23}$.

${ }^{20}$ Vintoko, Pakar Epidemiologi UI Ungkap Waktu Yang Tepat Untuk Memulai New Normal Tunggu Dulu, https://wow.tribunnews.com/2020/05/30/pakar-epidemiologi-ui-ungkap-waktu-yang-tepat-untukmemulai-new-normal-tunggu-dulu. Diakses 7 Juli 2020.

21 Tim Jurnal Presisi, Prediksi Jusuf Kalla New Normal Akan Dijalani Minimal Tiga Tahun, https://jurnalpresisi.pikiran-rakyat.com/nasional/pr-15391633/prediksi-jusuf-kalla-new-normal-akandijalani-minimal-tiga-tahun. Diakses 7 Juli 2020.

22 CNN Indonesia, Tiga Syarat Menuju The New Normal Versi Epidemiolog UI, https://www.cnnindonesia.com/nasional/20200520133813-20-505287/tiga-syarat-menuju-the-newnormal-versi-epidemiolog-ui. Diakses 7 Juli 2020.

${ }^{23}$ Kemendikbud, Guru Berbagi, https://guruberbagi.kemdikbud.go.id/. Diakses 7 Juli 2020. 


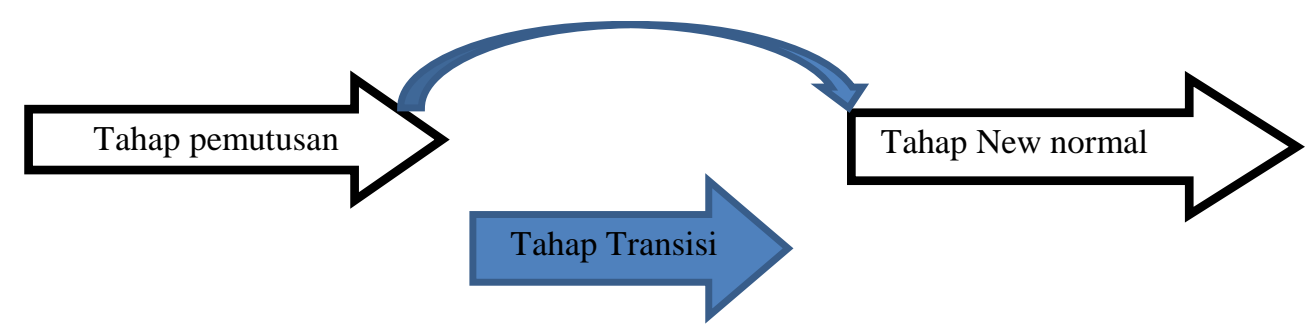

Penulis melihat, kebanyakan belum berhasil melewati fase pertama, masyarakat belum disiplin mengikuti protokol kesehatan, konsekuensinya menjadi sulit memasuki fase-fase berikutnya, yaitu tahap transisi, apalagi tahap new normal. Jika tahap transisi gagal melaksanakan perubahan, maka kemungkinan akan masuk ke jurang kehancuran dan sangat sulit untuk kembali bangkit menuju tahap new normal, sedangkan jika berhasil menjalani tahap transisi tersebut, maka tidak absurd akan terjadi peningkatan yang sangat signifikan menuju tahap new normal. Oleh karena itu penulis memandang pentingnya menyiapkan dan mengatur tahap transisi seproduktif dan seefektif mungkin sebelum menjalani new normal, sebagaimana indikator yang telah disahkan oleh WHO dan pemerintah.

\section{Strategi Pembelajaran di Masa Transisi New Normal}

Kontroversi masyarakat Indonesia tentang pembukaan sekolah di masa transisi menuju new normal menjadi semakin menggema dan sangat dilematik, tentu ini memiliki argumentasi masing-masing. Salah satu alasan bagi masyarakat yang pro dengan pembukaan sekolah adalah karena kondisi kas sekolah yang semakin menipis, sehingga membutuhkan pemasukan untuk menggaji para guru, teristimewa sekolah swasta. Sedangkan yang memprotes, kebanyakan datang dari orang tua/wali siswa. Mereka takut karena walaupun sudah masuk pada transisi new normal, kasus Covid-19 belum sepenuhnya berhenti. Bahkan jika melihat kasus positif semakin meningkat karena dilakukannya test dan tracing yang luar biasa oleh pemerintah ${ }^{24}$. Meniru dari Inggris, Jerman dan Vietnam, mengutip dari detik health 04 Juni 2020, 3 negara tersebut telah memutuskan untuk kembali pada New Normal dan membuka sekolah, namun tetap mengikuti protokol kesehatan yang sangat ketat, seperti Lorong sekolah hanya dipakai satu arah saja, wajib pakai masker, Siswa di

${ }^{24}$ Fahmi Syahirul, Jalan Tengah pembukaan Sekolah di Era New Normal, https://rmoljabar.id/jalantengah-pembukaan-sekolah-di-era-new-normal/. Diakses 6 Juli 2020. 
ruangan kelas dibatasi, waktu mengajar dibagi dua gelombang, Jarak kursi antara siswi satu dengan lainnya berjauhan sejauh 1,5 sampai 2 meter dan Jendela tetap dibuka untuk sirkulasi udara ${ }^{25}$.

Plt Dirjen PAUD, Pendidikan Dasar dan Pendidikan Menengah Kemendikbud menjelaskan bahwa Jika tahun ajaran ditunda atau dimundurkan ke Januari 2021, ada beberapa dampak dan penyelarasan sehingga tahun ajaran tetap dilaksanakan pada pertengahan Juli 2020 dengan pola belajar berbasis daring atau bukan belajar tatap muka" 26 .

Menanggapi hal tersebut, Ikatan Dokter Anak Indonesia (IDAI) mengusulkan kepada pemerintah agar sekolah tetap ditutup dan belajar online ${ }^{27}$. Di era internet seluler, negara-negara di seluruh dunia telah melakukan berbagai upaya efektif dalam pendidikan online, tetapi pendidikan online lebih merupakan pelengkap bagi pendidikan sekolah, dan pendidikan online normal berskala besar tidak memiliki banyak kasus. Kampanye "School Out, But Class's on" diluncurkan oleh pemerintah Cina selama epidemi COVID19 menciptakan aplikasi pendidikan online skala besar yang normal28.

Pada tanggal 15 Juni 2020, Kementerian Pendidikan dan Kebudayaan, Kementerian Agama, Kementerian Kesehatan, dan kementerian dalam Negeri memutuskan untuk menyusun panduan penyelenggaraan pembelajaran pada tahun ajaran dan tahun akademik baru di masa COVID 19. Prinsip Kebijakan Pendidikan di Masa Pandemi COVID-19 dengan prinsip kebijakan bahwa kesehatan dan keselamatan peserta didik, pendidik, tenaga kependidikan, keluarga, dan masyarakat merupakan prioritas utama dalam menetapkan kebijakan pembelajaran. Adapun pola Pola pembelajaran pendidikan anak usia dini, pendidikan dasar dan pendidikan menengah yaitu ajaran baru 2020/2021

\footnotetext{
${ }^{25}$ Nafilah Sri Sagita K, 3 Negara Sudah Mulai Buka Sekolah Bagaimana New Normal diterapkan, https://health.detik.com/berita-detikhealth/d-5039896/3-negara-sudah-mulai-buka-sekolah-bagaimananew-normal-diterapkan. Diakses 6 Juli 2020.

26 Tim PRMN, Kemendikbud Tegaskan Tahun Ajaran Baru Tidak Mundur ke Januari 2021, https://www.pikiran-rakyat.com/pendidikan/pr-01390597/kemendikbud-tegaskan-tahun-ajaran-barutidak-mundur-ke-januari-2021. Diakses 7 Juli 2020.

27 Ayunda Pininta Kasih, Ikatan Dokter Anak Indonesia Anjurkan Sekolah Tidak dibuka Sampai Desember 2020, https://www.kompas.com/edu/read/2020/05/31/061839671/ikatan-dokter-anak-anjurkansekolah-tidak-dibuka-sampai-desember-2020. Diakses 7 Juli 2020.

${ }^{28}$ Longjun Zhou et al., "School's Out, But Class' On', The Largest Online Education in the World Today: Taking China's Practical Exploration During The COVID-19 Epidemic Prevention and Control As an Example, ”SSRN Electronic Journal, 2020, 501. https://doi.org/10.2139/ssrn.3555520.
} 
Tafkir: Interdisciplinary Journal of Islamic Education

Vol.1, No.1, June 2020, , DOI:

Hal: 20-40, E-ISSN-

tetap dimulai pada bulan Juli 2020, untuk daerah yang berada di zona kuning, oranye, dan merah, dilarang melakukan pembelajaran tatap muka di satuan pendidikan, satuan pendidikan pada zona-zona tersebut tetap melanjutkan Belajar dari Rumah ${ }^{29}$ New normal di sektor pendidikan itu sangat berbeda dari sektor-sektor kehidupan lainnya, sehingga harus penuh siaga dan cermat ${ }^{30}$.

Berdasarkan situasi tersebut, manajemen darurat umum menjadi solusi terbaik. Inisiatif kebijakan darurat yang disebut "Suspending Classes Without Stopping Learning atau penangguhan kelas tanpa menghentikan pembelajaran" bertujuan untuk mengubah kegiatan pengajaran menjadi pengajaran online ${ }^{31}$. Pembelajaran jarak jauh atau online telah menjadi norma ${ }^{32}$. Pembelajaran online sangat dibutuhkan untuk mengimbangi perkembangan dunia pendidikan yang didukung oleh teknologi informasi yang mengarah ke era digital baik proses maupun konten di era revolusi industri 4.0. Dengan pembelajaran online, proses pembelajaran dapat terjadi di mana saja dan kapan saja secara fleksibel ${ }^{33}$.

Pendidikan pada masa darurat ini perlu dibedakan dari periode normal. Adapun maksud "Penutupan kelas tanpa menghentikan pembelajaran" mencerminkan pembelajaran dalam arti luas, yang tidak hanya merujuk pada pembelajaran terstruktur dari kurikulum sekolah, tetapi juga mencakup pembelajaran berbagai konten. Pembelajaran semacam itu dapat dilakukan dengan berbagai usaha, yang tujuannya adalah untuk mendukung pertumbuhan siswa. Sementara itu, ditekankan bahwa pengetahuan pencegahan dan pengendalian epidemi perlu dimasukkan sebagai tambahan pada kurikulum nasional formal, dengan penekanan khusus pada

\footnotetext{
${ }^{29}$ Satuan Tugas Penanganan Covid-19. Panduan Penyelenggaraan Pembelajaran Pada Tahun Ajaran dan Tahun Akademik Baru di Masa Pandemi Corona Virus Disease (Covid-19), https://covid19.go.id/p/protokol/panduan-penyelenggaraan-pembelajaran-tahun-ajaran-baru-di-masapandemi-covid-19. Diakses 7 Juli 2020.

30 Nur Aini, Jokowi Ingatkan Daerah Tak Buru Buru Terapkan New Normal, https://republika.co.id/berita/qcq1h5382/jokowi-ingatkan-daerah-tak-buru-buru-terapkan-new-normal. Diakses 7 Juli 2020.

31 Wunong Zhang et al., "Suspending Classes Without Stopping Learning: China's Education Emergency Management Policy in the COVID-19 Outbreak, ” Journal of Risk and Financial Management, Vol. 13 (3), 2020, 1. https://doi.org/10.3390/jrfm13030055.

${ }^{32}$ Samantha L. Schneider and Martha Laurin Council, "Distance Learning in the Era of COVID-19," Archives of Dermatological Research, 2020, 1. https://doi.org/10.1007/s00403-020-02088-9.

${ }^{33}$ Unung Verawardina et al., "Reviewing Online Learning Facing the Covid-19 Outbreak, " Talent Development and Excellence, Vol. 12, 2020, 385.
} 
mempopulerkan pengetahuan pencegahan epidemi, diekspresikan melalui kelas pendidikan kehidupan, pendidikan keselamatan publik dan pendidikan kesehatan mental 34 .

Pendidikan keselamatan publik melalui Implementasi kebijakan sangat penting diperhatikan mulai dari proses yang dinamis, sistem manajemen darurat hingga menghubungkan antara tujuan dari semua langkah, sepatutnya bagi pihak sekolah, (kepala sekolah, guru dan orang tua) berkolaborasi untuk menerapkan sistem manajemen darurat publik yaitu sebuah prosedur yang memungkinkan pengambilan keputusan darurat dan sirkulasi informasi yang terpusat, dan sebuah sistem untuk manajemen kelas dan respons multi-level ${ }^{35}$.

\section{Manajemen Sumber Daya Manusia (MSDM) dalam Meningkatkan Strategi Pembelajaran di Era New Normal Transition}

Beberapa sekolah di Indonesia diliburkan guna mencegah penyebaran COVID 19, maka pihak yang sangat dirugikan adalah segenap civitas akademi, apabila sekolah diliburkan. Namun apabila dicermati secara akurat, siswa adalah pihak yang paling merasakan imbasnya. Permasalahannya, apabila pembelajaran terhenti atau diundur maka waktu pelaksanaan kegiatan belajar selama setahun akan mundur sampai batas waktu yang tidak ditentukan. Maka dari itu sangat diperlukan pendidikan yang berorientasi pada global relevant need yaitu kebutuhan yang relevan.

Untuk itu, pendidikan memerlukan sumberdaya yang handal, baik sumberdaya manusia maupun sarana prasarana bagi efisiensi pendidikan. Adanya Covid-19 telah mendorong guru dan tenaga akademik sekolah mengambil sejumlah kebijakan terkait dengan kegiatan pembelajaran. Sebagai personal yang terjun di dunia pendidikan, Faktanya, penulis melihat adanya dampak dari kebijakan belajar di rumah bagi siswa yang dimulai sejak bulan Maret ini. Agenda yang sudah terjadwal menjadi berantakan, sehingga mau tak mau lembaga pendidikan juga harus melakukan evaluasi kebijakan guna mengantisipasi dampak Covid 19 ini. Ujian Nasional yang ditiadakan,

\footnotetext{
${ }^{34}$ Zhang et al., "Suspending Classes Without Stopping Learning. 2.

${ }^{35}$ Haedar Akib, "Implementasi Kebijakan: Apa, Mengapa dan Bagaimana," Jurnal Ilmiah Ilmu Administrasi Publik, Vol. 1 (1), 2012, 2, https://doi.org/10.26858/jiap.v1i1.289.
} 
Tafkir: Interdisciplinary Journal of Islamic Education

Vol.1, No.1, June 2020, , DOI:

Hal: 20-40, E-ISSN-

kemudian Ujian akhir sekolah yang harus diselenggarakan via WhatsApp merupakan salah satu perubahan yang dihadapi. Manajemen lembaga pendidikan harus mampu beradaptasi dengan pandemi ini dan dituntut agar tetap bisa menjalankan agenda rutin yang sudah terjadwal meski tetap menjaga sosial distanscing maupun psychical distanscing.

Ketika pembelajaran di lembaga pendidikan terhenti akibat wabah ini, maka dari itu opini publik terhadap lembaga pendidikan terutama guru akan menjadi semakin positif. Kaitannya dengan kompetensi professional maka guru harus menguasai, antara lain:

1. Materi, struktur, konsep, dan pola pikir keilmuan yang mendukung pelajaran yang digajar.

2. Memahami standar kompetensi dan kompetensi dasar mata pelajaran/bidang pengembangan yang diajar.

3. Mengelaborasikan materi pembelajaran yang dimampu secara kreatif.

4. Menumbuhkan keprofesionalan secara berkelanjutan dengan melakukan tindakan instrospektif.

5. Mampu menggunakan TIK untuk berkomunikasi dan mengembangkan diri ${ }^{36}$.

Berkali-kali disinggung di atas, bahwa sangat diperlukan kerjasama dan manajemen yang sudah terstruktur, baik itu guru, kepala sekolah dan orang tua wali untuk mampu menyajikan pembelajaran daring. Kepala sekolah dengan kedudukannya yang begitu strategis harus mampu menampilkan kepemimpinan yang efektif, manajemen sekolah yang baik harus disertai oleh guru baik, sehingga kurikulumnya dapat diterjemahkan menjadi pembelajaran yang baik. Keefektifan suatu sekolah dalam menggapai visi, mengemban misi, mememuni tujuan dan target, serta dalam menjalankan aktivitas pembelajaran mempersyaratkan adanya seorang kepala sekolah yang menampilkan kepemimpinan yang efektif 37

\footnotetext{
${ }^{36}$ Wakhudin Dkk, Covid-19 Dalam Ragam Tinjauan........., 65.

${ }^{37}$ Mbs center, Penguatan Manajemen Pendidikan Persekolahan dalam Rangka Menghasilkan Sumber Daya Manusia Di Era Kompetisi Global,

http://www.mbscenter.or.id/site/page/id/459/title/Penguatan\%20Manajemen\%20Pendidikan\%20Persekol ahan\%20Dalam\%20Rangka\%20Menghasilkan\%20Sumber\%20Daya\%20Manusia\%20Di\%20Era\%20Ko mpetisi\%20Global. Diakses 07 Juli 2020.
} 
Adapun Bentuk-bentuk manajemen sekolah yang bisa diterapkan di era new normal antara lain: ${ }^{38}$

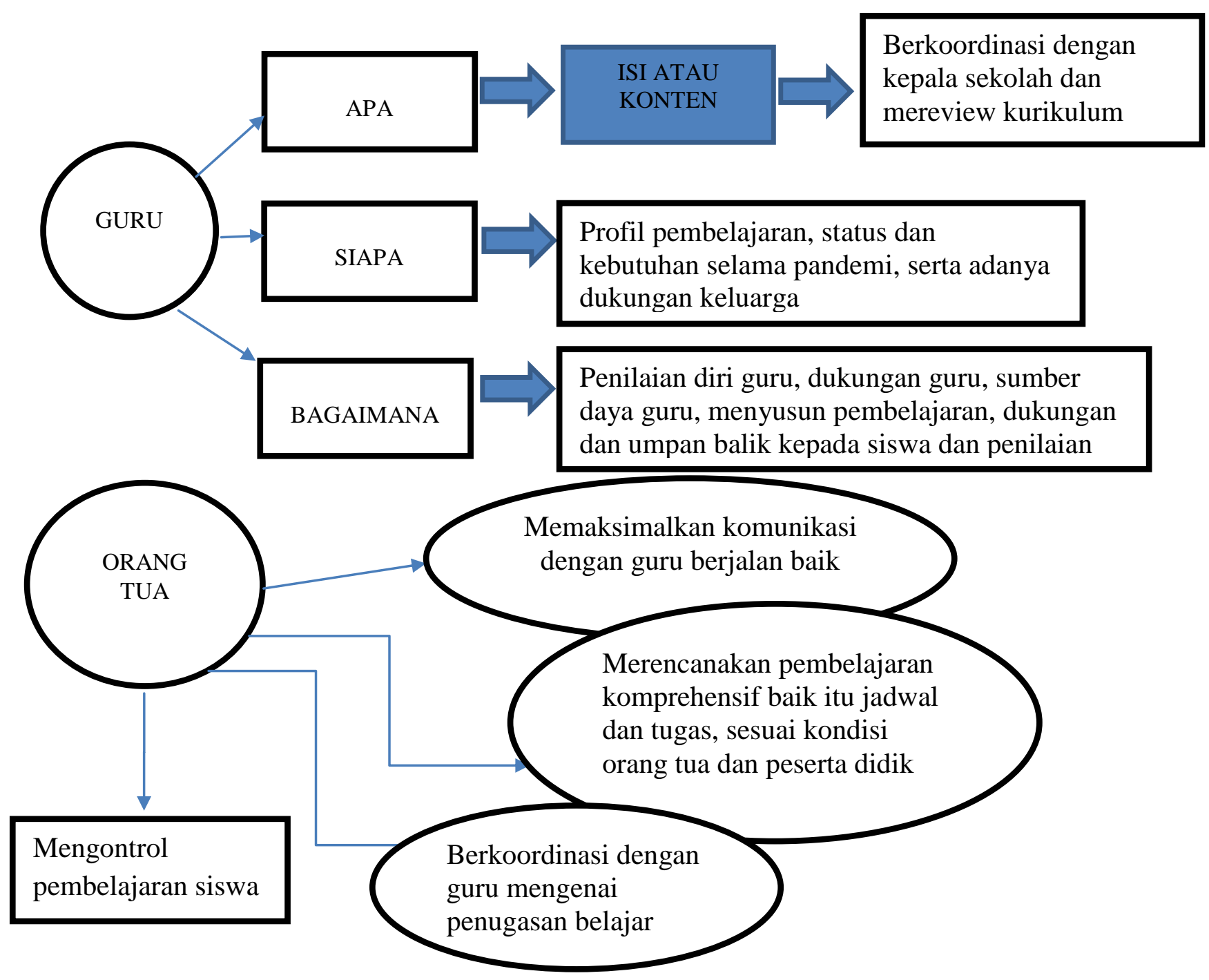

Gambar 2. Bentuk Manajemen Sekolah

Sumber: Kemendikbud

\section{KESIMPULAN}

Manajemen SDM dalam meningkatkan strategi pembelajaran di era new normal adalah dengan upaya, kesiapan matang, pembekalan baik dari segi kecakapan TIK dan keterbiasaan berlangsungnya virtual learning. Mungkin pandemi adalah awal pencetus maraknya atau ditetapkannya aturan belajar online bagi siswa d Indonesia oleh Pemerintah dan Kemendikbud sendiri, walaupun sebelumnya

\footnotetext{
${ }^{38}$ Kemendikbud, Guru berbagi, https://guruberbagi.kemdikbud.go.id/.
} 
Tafkir: Interdisciplinary Journal of Islamic Education

Vol.1, No.1, June 2020, , DOI:

Hal: 20-40, E-ISSN-

sekolah-sekolah elite, bonafit sudah lebih dulu menginjakkan kaki belajar dengan memanfaatkan teknologi tetapi bisa dipastikan tidak terlalu mendominasi seperti sebelum pandemic terjadi. Untuk itu 2 elemen pokok berlangsung kegiatan belajarmengajar, siswa dan guru ini harus dibekali, mumpuni dan tau arah belajar yang di filterisasi agar meminimalisir kesalahanpahaman antara guru dan siswa. Sementara siswa, di rumah, belajar dibantu dan diawasi oleh orangtuanya agar tidak terjadi tipu daya, kemalasan dan kecurangan saat pelaksanaan ujian. Sehingga etika, nilai/norma tetap dijunjung tinggi dalam dunia akademisi. Inilah strategi pembelajaran yang paling tepat di era new normal ini, Perubahan zaman yang begitu cepat, siap ataupun tidak harus diikuti oleh semua daerah jika tidak mau terbelakang. Terdapat perubahan dan tantangan besar yang di hadapi dengan tetap menjalankan aktivitas di tengah pandemi, tapi ini merupakan solusi. Dari sinilah siswa bisa belajar dengan situasi pandemi, dan tetap dimotivasi serta dibimbing guru untuk bisa sukses di masa mendatang.

\section{REFERENSI}

Aprilianto. (2019). Manajemen SDM, Yogyakarta: Bening Pustaka.

Ahmad, Iqbal Faza. (2020). Alternative Assessment in Distance Learning in Emergencies Spread of Coronavirus Disease (Covid-19) in Indonesia. Jurnal $\begin{array}{lllll}\text { Pedagogik. } & \text { Vol, } & 07 & \text { (1), 195-222. }\end{array}$ https:// ejournal.unuja.ac.id/index.php/pedagogik\%0AALTERNATIVE.

Akib, Haedar. (2010). Implementasi Kebijakan: Apa, Mengapa dan Bagaimana. Jurnal Ilmiah Ilmu Administrasi Publik. Vol. 1 (1), 1-11. DOI: https:// doi.org/10.26858/jiap.v1i1.289.

Albertus Adit. (2020, 26 Mei), Padanan Kata New Normal dari Badan Bahasa Kemendikbud. Retrieved Juli 7, 2020, from

https://edukasi.kompas.com/read/2020/05/26/152138171/ini-padanan-kata-newnormal-dari-badan-bahasa-kemendikbud.

Abdul Basith Bardan. (2020, Mei 20). Pemerintah Siapkan Tiga Syarat Penyesuaian PSBB. Retrieved Juli 7, 2020, from https://nasional.kontan.co.id/news/pemerintahsiapkan-tiga-syarat-penyesuaian-psbb.

Ayunda Pininta Kasih. (2020, Mei 31). Ikatan Dokter Anak Indonesia Anjurkan Sekolah Tidak dibuka Sampai Desember 2020. Retrieved Juli 7, 2020, from

https://www.kompas.com/edu/read/2020/05/31/061839671/ikatan-dokter-anakanjurkan-sekolah-tidak-dibuka-sampai-desember-2020.

CNN Indonesia. (2020, Mei 20). Tiga Syarat Menuju The New Normal Versi Epidemiolog UI. Retrieved Juli 7, 2020, from 
https:/ / www.cnnindonesia.com/nasional/20200520133813-20-505287/tiga-syaratmenuju-the-new-normal-versi-epidemiolog-ui.

Darmalaksana, Wahyudin. (2020). New Normal Perspektif Sunnah Nabi Saw. Fakultas Ushuluddin UIN Sunan Gunung Djati Bandung, 2020, 1-5.

http:/ / digilib.uinsgd.ac.id/id/eprint/31093, diakses 3 Juli 2020.

DH Santoso, A Santosa, Ed. (2020). Covid-19 dalam Ragam Tinjauan. D.I. Yogyakarta: MBridge Press. Diakses dari https://scholar.google.co.id/scholar?hl=id\&as_sdt=0\%2C5\&q=Covid19+dalam+Ragam+Tinjauan.\&btnG=, tanggal 8 Juli 2020.

Fahmi Syahirul. (2020, Juni 15). Jalan Tengah pembukaan Sekolah di Era New Normal. Retrieved Juli 6, 2020, from https://rmoljabar.id/jalan-tengah-pembukaansekolah-di-era-new-normal/.

H.M. Jogiyanto. (2018). Sistem Informasi Manajemen, Tangerang Selatan: Universitas Terbuka.

Handoko, T. H. (1991). Manajemen. Yogyakarta: BPFF.

Kartiko. (2019). Manajemen Mutu Pendidikan, Yogyakarta: Bening Pustaka.

Kurniadi. (2020, 4 Juni), Menyiapkan Pendidikan Menuju Normal Baru. Retrieved Juli 7, 2020, from http://www.untan.ac.id/menyiapkan-pendidikan-menuju-normalbaru/.

Kemendikbud. (2020). Guru berbagi:Gerakan Gotong Royong, Guru Berdaya Hadapi Corona. Retrieved Juli 7, 2020, from https://guruberbagi.kemdikbud.go.id/.

Satuan Tugas Penanganan Covid-19. (2020, Juni 24). Panduan Penyelenggaraan Pembelajaran Pada Tahun Ajaran dan Tahun Akademik Baru di Masa Pandemi Corona Virus Disease (Covid-19). Retrieved Juli 7, 2020, from https://covid19.go.id/p/protokol/panduan-penyelenggaraan-pembelajarantahun-ajaran-baru-di-masa-pandemi-covid-19.

Muslih, Basthoumi. (2020), Urgensi Komunikasi dalam Menumbuhkan Motivasi di Era Pandemi Covid-19. Jurnal Penelitian Manajemen Terapan (PENATARAN). Vol. 5 (1), $57-65$.

DOI: http://journal.stieken.ac.id/index.php/penataran/article/view/463.

Nasution. M. Nur. (2015). Manajemen Mutu Terpadu, Bogor: Ghalia Indonesia.

Nefan Kristiono. (2020, Mei 20). Pengertian New Normal Versi Achmad Yurianto, Retrieved Juli 07, 2020, from https://www.minews.id/news/ini-pengertiannew-normal-versi-achmad-yurianto-2.

Nafilah Sri Sagita K. (2020, Juni 4). 3 Negara Sudah Mulai Buka Sekolah Bagaimana New Normal diterapkan. Retrieved Juli 6, 2020, from https://health.detik.com/beritadetikhealth/d-5039896/3-negara-sudah-mulai-buka-sekolah-bagaimana-newnormal-diterapkan.

Nur Aini. (2020, Juni 30). Jokowi Ingatkan Daerah Tak Buru Buru Terapkan New Normal. , 2020, Retrieved Juli 7, 2020, from https:// republika.co.id/berita/qcq1h5382/jokowi-ingatkan-daerah-tak-buruburu-terapkan-new-normal. 
Tafkir: Interdisciplinary Journal of Islamic Education

Vol.1, No.1, June 2020, , DOI:

Hal: 20-40, E-ISSN-

Mbs center. (2020, April 4). Penguatan Manajemen Pendidikan Persekolahan dalam Rangka Menghasilkan Sumber Daya Manusia di Era Kompetisi Global. Retrieved Juli 7, 2020, from

http://www.mbscenter.or.id/site/page/id/459/title/Penguatan\%20Manajeme n\%20Pendidikan\%20Persekolahan\%20Dalam\%20Rangka\%20Menghasilkan\%20S umber\%20Daya\%20Manusia\%20Di\%20Era\%20Kompetisi\%20Global

Ridwan Sanjaya. (2018). New Normal dalam Pendidikan Tinggi. Retrieved Juli 7, 2020, From http://www.suaramerdeka.com/smcetak/detail/124756.

Redaksi WE Online. (2020, Mei 20). Syarat Penerapan The New Normal dari WHO Apa saja. Retrieved Juli 7, 2020, from https:// www.wartaekonomi.co.id/read286402/6-syarat-penerapan-the-newnormal-dari-who-apa-saja.

Rizqulloh, Ridho. (2020). E-Learning dan Pembelajaran Jarak Jauh (PJJ) Saat Masa Pandemi Covid-19, 1-7.

https://www.researchgate.net/publication/340920188\%0AARTIKEL, diakses 8 Juli 2020.

Schneider, Samantha L., \& Martha Laurin Council. (2020). Distance Learning in the Era of COVID-19. Archives of Dermatological Research, 1-2. DOI: https:// doi.org/10.1007/s00403-020-02088-9.

Taufik, Hardi Warsono. (2020). Birokrasi Baru Untuk New Normal: Tinjauan Model Perubahan Birokrasi dalam Pelayanan Publik di Era Covid-19. Dialogue Jurnal Ilmu Administrasi Publik. Vol.2 (1), 1-18.

https://www.researchgate.net/publication/340920188\%0AARTIKEL, diakses 9 Juli 2020.

Tim Jurnal Presisi. (2020, Mei 31). Prediksi Jusuf Kalla New Normal Akan Dijalani Minimal Tiga Tahun. Retrieved Juli 7, 2020, from https://jurnalpresisi.pikiranrakyat.com/nasional/pr-15391633/prediksi-jusuf-kalla-new-normal-akandijalani-minimal-tiga-tahun.

Tim PRMN. (2020, Mei 2020). Kemendikbud Tegaskan Tahun Ajaran Baru Tidak Mundur ke Januari 2021. Retrieved Juli 7, 2020, from https://www.pikiranrakyat.com/pendidikan/pr-01390597/kemendikbud-tegaskan-tahun-ajaranbaru-tidak-mundur-ke-januari-2021/

Verawardina, Unung et all. (2020). Reviewing Online Learning Facing the Covid-19 Outbreak. Talent Development and Excellence.Vol. 12, 385-392. https:// web.a.ebscohost.com/abstract?direct=true\&profile=ehost\&scope=site\&a uthtype $=$ crawler\&jrnl $=18690459 \& A N=144289555 \&$ h=TEvf4mJDWntGDDvPqNF e4To9Xr0sYCMEtJ5PzZVHcVbZixFFcarz\%2bH2Th22lWbdMBbx\%2f3q2HaktssQ 31YMyk5w\%3d\%3d\&crl=c\&resultNs=AdminWebAuth\&resultLocal=ErrCrlNot Auth\&crlhashurl=login.aspx\%3fdirect\%3dtrue\%26profile\%3dehost\%26scope \%3d site\%26authtype\%3dcrawler\%26jrnl\%3d18690459\%26AN\%3d144289555, diakses 5 Juli 2020. 
Vintoko. (2020, Mei 30). Pakar Epidemiologi UI Ungkap Waktu Yang Tepat Untuk Memulai New Normal Tunggu Dulu. Retrieved Juli 7, 2020, from

https://wow.tribunnews.com/2020/05/30/pakar-epidemiologi-ui-ungkap-waktuyang-tepat-untuk-memulai-new-normal-tunggu-dulu.

Winarsih, R. d. (2016). Manajemen Pelayanan: Pengembangan Model Konseptual, Penerapan Citizen's Charter dan Standar Pelayanan Minimal. Yogyakarta: Pustaka Pelajar.

Zhou, Longjun, Fangmei li, Shanshan Wu \& Ming Zhou. (2020). School's Out, But Class' On', The Largest Online Education in the World Today: Taking China's Practical Exploration during the COVID-19 Epidemic Prevention and Control as an Example. Best Evid Chin Edu 2020. 4(2), 501-519. Available at SSRN: https:// ssrn.com/abstract=3555520 or http://dx.doi.org/10.2139/ssrn.3555520.

Zhang, Wunong, Yuxin Wang, Lili Yang, \& Chuanyi Wang. (2020). Suspending Classes Without Stopping Learning: China's Education Emergency Management Policy in the COVID-19 Outbreak. Journal of Risk and Financial Management, Vol. 13 (3), 16. DOI: https:// doi.org/10.3390/jrfm13030055. 